\title{
OXIDATIVE STRESS PARAMETERS AFTER ABDOMINAL HYSTERECTOMY AND THEIR RELATIONSHIPS WITH QUALITY OF RECOVERY
}

Danijela Jovanovic ${ }^{1}$, Dragan R. Milovanovic ${ }^{2}$, Nevena Jeremic $^{3}$, Tamara Nikolic ${ }^{3}$, Isidora Stojic ${ }^{3}$, Vladimir Jakovljevic ${ }^{3,4}$, Natalija Vukovic $^{5}$ ${ }^{1}$ Department of Anesthesiology and Reanimatology, Clinical Centre "Kragujevac", Kragujevac, Serbia

${ }^{2}$ Department of Clinical Pharmacology, Clinical Centre "Kragujevac", Faculty of Medical Sciences University of Kragujevac, Kragujevac, Serbia ${ }^{3}$ Department of Physiology, Faculty of Medical Sciences University of Kragujevac, Kragujevac, Serbia ${ }^{4}$ Department of Human Pathology, 1st Moscow State Medical University IM Sechenov, Moscow, Russia ${ }^{5}$ Departement of Anesthesiology and Reanimatology, Clinical Centre „Nis “, Nis, Serbia

\section{PARAMETRI OKSIDATIVNOG STRESA POSLE ABDOMINALNE HISTEREKTOMIJE I NJIHOVA POVEZANOST \\ SA KVALITETOM OPORAVKA}

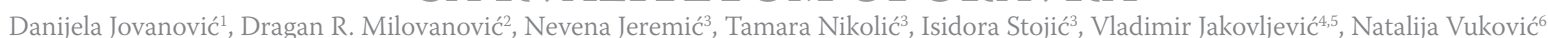
${ }^{1}$ Služba za anesteziologiju i reanimatologiju, Klinički centar "Kragujevac", Kragujevac

${ }^{2}$ Služba za kliničku farmakologiju, Klinički centar “Kragujevac”, Fakultet medicinskih nauka Univerziteta u Kragujevcu, Kragujevac ${ }^{3}$ Institut za fiziologiju, Fakultet medicinskih nauka Univerzitet u Kragujevcu, Kragujevac

${ }^{4}$ Institut za humanu patologiju, Prvi Moskovski državni medicinski univerzitet "Sečenov", Moskva, Rusija ${ }^{6}$ Centar za anesteziologiju i reanimatologiju, Klinički centar "Niš", Niš

\section{ABSTRACT}

Study aimed to investigate relationship between oxidative stress markers and postoperative recovery in woman after abdominal hysterectomy, as well as to test the hypothesis that different analgesics differently influence redox status.

The quality of recovery was evaluated with a QoR-40 questionnaire in fifty-one patients who underwent $a b$ dominal hysterectomy, preoperatively and on the $1^{\text {st }}, 2^{\text {nd }}$, $3^{\text {rd }}$ postoperative days (POD1,2,3). Blood samples were collected at baseline (T0), 3 (T1), 24 (T2), 48 (T3) and 72 (T4) hours after surgery. Oxidative stress markers concentrations ( TBARS, $\mathrm{NO}_{2}^{-}, \mathrm{H}_{2} \mathrm{O}_{2} \mathrm{O}_{2}^{-}$) as well as antioxidative enzymes (SOD, CAT, and GSH) were analyzed.

QoR-40 total score significantly declined on POD1 and POD2 and returned to baseline levels on POD3 $(p<0.001)$. $\mathrm{H}_{2} \mathrm{O}_{2}$ levels significantly decreased from $\mathrm{TO}$ to $\mathrm{T3}$ and then, increased at T4 $(p=0,011)$. Changes of TBARS and $\mathrm{H}_{2} \mathrm{O}_{2}$ from TO to T3 showed significant and negative correlation ( $r=-0.303, p=0.046)$. There was no significant correlation between QoR-40 total score and any parameter of oxidative stress response ( $p>0.05)$. Changes in TBARS levels from TO to T3 were statistically significant between the study subgroups primarily due to increase of the concentrations in patients receiving paracetamol $(p=0.031)$. Patients age, duration of surgery and cigarette smoking status showed significant influcences on and association with some oxidative stress response markers (TBARS, $\left.\mathrm{O}_{2}^{-}, \mathrm{CAT}\right)(\mathrm{p}<0.05)$.

Women who underwent hysterectomy had significant changes of $\mathrm{H}_{2} \mathrm{O}_{2}$ and TBARS activity however, those changes were not associated with changes of QoR-40 total scores during recovery.

Keywords: hysterectomy; postoperative period; oxidative stress.

\section{SAŽETAK}

Studija je imala za cilj da ispita povezanost između markera oksidativnog stresa i postoperativnog oporavka kod pacijentkinja podvrgnutih abdominalnoj histrektomiji kao $i$ da testira hipotezu da različiti analgetici različito utiču na redoks status.

Kod 51 pacijentkinje podvrgnute abdominalnoj histrektomiji zbog benigne bolesti uterusa kvalitet postoperativnog oporavka je evaluiran sa upitnikom QoR-40, preoperativno, kao i prvog, drugog i trećeg postoperativnog dana (POD 1, $2 i$ 3). Uzorci krvi su uzeti preoperativno (T0), 3 (T1), 24 (T2), 48 (T3) $i 72$ (T4) sata posle operacije. Analizirane su koncentracije markera oksidativnog stresa (TBARS, $\mathrm{NO}_{2}, \mathrm{H}_{2} \mathrm{O}_{2}, \mathrm{O}_{2}^{-}$) kao i enzima antioksidacione odbrane (SOD, CAT $i$ GSH).

Vrednosti ukupnog QoR-40 skora su značajno opale u POD1 $i$ POD2 $i$ vratile se na preoperativne vrednosti $u$ POD3 (p<0.001). Koncentracije $\mathrm{H}_{2} \mathrm{O}_{2}$ su značajno opale od TO do T3 i porasle u T4 $(p=0,011)$. Promene od TO do T3 $u$ vrednostima TBARS-a $i \mathrm{H}_{2} \mathrm{O}_{2}$ su u značajnoj međusobnoj negativnoj korelaciji ( $r=-0.303, p=0.046)$. Nije bilo značajne korelacije između ukupnog QoR-40 skora i bilo kog parametra oksidativnog stresa $(p>0.05)$. Promene vrednosti TBARS-a od TO do T3 su bile značajno različite izmedu studijskih podgrupa pre svega zbog porasta koncentracija kod pacijentkinja koji su primale paracetamol ( $p=0.031)$. Starost pacijenata, trajanje operacije kao i pušenje pokazali su povezanost sa pojedinim markerima stres odgovora (TBARS, $\mathrm{O}_{2}$, CAT $)(p<0.05)$

Kod pacijentkinja podvrgnutih histerektomiji dolazi do značajnih promena $\mathrm{u}_{2} \mathrm{O}_{2} i \mathrm{TBARS}$-u, ali one nisu značajno udružene sa kvalitetom oporavka.

Ključne reči: histrektomija; postoperativni oporavak; oksidacioni stres. 


\section{ABBREVIATIONS}

ASA -American Society of Anesthesiologist physical status classification

CAT- catalase

ECG - electrocardiogram EtCO - end tidal carbon dioxide GSH - reduced glutathione $\mathbf{H}_{2} \mathbf{O}_{2}$ - hydrogen peroxide MAC - minimum alveolar concentration MDA - malonyldialdehyde NIBP - non-invasive blood pressure NO - nitric oxide
$\mathrm{NO}_{2}^{-}$- nitrite

NPRS - numeric pain rating scale

NSAID - non-steroidal anti-inflammatory drugs

$\mathbf{O}_{2}^{-}$- superoxide anion radical

PACU - post-anesthesia care unit

POD- postoperative day

QoR-40 - quality of recovery 40-item questionnaire

SOD - superoxide dismutase

SpO - peripheral capillary oxygen saturation

TBARS - thiobarbituric acid reactive substances

GPx - glutathione peroxidase

\section{INTRODUCTION}

The abdominal hysterectomy, the most common major gynecological procedure, disturb patients quality of life during postoperative period despite of modern advances in both surgery and anesthesia $(1,2)$. Re-establishing physical and psychological balance as well as disappearing of unpleasant symptoms, take certain amount of time during period known as postoperative recovery (3). Since postoperative recovery is nowadays recognized as a valid clinical outcome, many efforts have been done in developing instruments for its measurement as well as for exploring its pathophysiological basis $(4,5)$.

Surgical trauma activates several biological pathways and among them, there is increased production of reactive species causing the state known as the oxidative stress (6, $5)$. On the other side, the researchers have found positive association between increased oxidative stress markers and some symptoms, which participated in health-related quality of life perception like fatigue, depression, anxiety, nausea and headache (7-10). Although patients are combating with many of these symptoms during postoperative recovery the studies, which measured quality of life after surgery in details, and using validated rating questionnaires were not common.

Some additional issues increase the complexity of the matter and, consequently, the need for further investigations. For example, the synthesis of reactive species depends on the type and the extent of the intervention, anesthesia techniques and anesthetics (11-14). In addition, analgesics could modulate oxidative stress response during postoperative period either decreasing (e.g. morphine) or increasing it (e.g. ibuprofen) $(15,16)$. In some cases, researchers elucidated the mechanisms of stress response alterations in fine details. Paracetamol, a phenolic compound, has a large antioxidative capacity due to inhibition of myeloperoxidase, the enzyme that generates the high amounts of the pro-oxidants (17). Therefore, the studies investigating the oxidative stress response after surgery in the variety of settings and with the diversity of putative modulators are still necessary.
The current knowledge about oxidative stress markers after abdominal hysterectomy is much less than those concerning other major surgeries with more profound ischemia-reperfusion injury (e.g. vascular, cardiologic surgery, tourniquet-used interventions). Abdominal hysterectomy triggers detectable changes of oxidative stress status and studies identified several factors that contributed to production of free radicals during the intervention (e.g. peritoneal closure, retention of ovaries, hormonal changes) (18-20). However, we are not aware of any study that simultaneously investigated the relationships of oxidative stress parameters and postoperative recovery as well as the effects of therapeutic interventions.

Therefore, in this study, we hypothesized that oxidative stress injury after abdominal hysterectomy deteriorated quality of life during the postoperative recovery period and that multimodal analgesia with analgesics, that have proven or proposed antioxidant activity, will give faster recovery measured with a validated rating questionnaire.

\section{PATIENTS AND METHODS}

The study was designed as interventional, time-series, non-therapeutic trial within which there was four groups of patients according to the primary analgesic drug given during the early postoperative recovery. The cohort was formed from women who were underwent abdominal hysterectomy in Clinical Center "Kragujevac", Kragujevac, Serbia, successively, from October 2011 to February 2013, up to the number of pre-calculated total sample size. Eligible subjects met the following inclusion criteria: females, total abdominal hysterectomy due to benign disease (leiomyoma), ASA physical status I or II and the receiving one or two of the study analgesics (morphine, ketoprofen, ketorolac, paracetamol). Exclusion criteria were: previous chronic use of anti-inflammatory drugs (i.e. steroids, NSAIDs), antipsychotics and opioids, known previous hypersensitivity to study drugs and history of medi- 
cally important kidney or liver disease. The study design was comparable with similar previous published studies $(1,4)$. Study approval was obtained from Clinical Center Kragujevac Institutional Ethics Review Board and all study participants gave the written informed consent.

\section{Anesthesia and analgesia}

All patients were premedicated with $0.07 \mathrm{mg} / \mathrm{kg}$ i.m. midazolam and during anesthesia, standard monitoring were applied (ECG, NIBP, $\mathrm{SpO}_{2}, \mathrm{EtCO}_{2}$ and capnography). Induction of anesthesia was achieved with fentanyl 2-3 $\mathrm{mcg} / \mathrm{kg}$ i.v., propofol $1.5-2.0 \mathrm{mg} / \mathrm{kg}$ i.v. rocuronium $0.6 \mathrm{mg} /$ $\mathrm{kg}$ i.v. Patients were ventilated with an oxygen-air mixture $\left(\mathrm{FiO}_{2}=0.4\right)$ and $\mathrm{EtCO}_{2}$ stabilized at $35-40 \mathrm{~mm} \mathrm{Hg}$. Anesthesia was maintained the with sevoflurane at 1-1,5 minimum alveolar concentration (MAC), fentanyl $1 \mathrm{mcg} / \mathrm{kg}$ titrated to the dose which avoided the increase arterial blood pressure values above $20 \%$ of baseline, and additional doses of rocuronium to keep satisfactory surgical relaxation. All patients received ondansetron $4 \mathrm{mg}$ prior to the end of surgery. Neuromuscular blockade was antagonized with 0.05 $\mathrm{mg} / \mathrm{kg}$ i.v. neostigmine and $0.01 \mathrm{mg} / \mathrm{kg}$ i.v. atropine. Patients were awakened and extubated in the operating room and transferred to the post-anesthesia care unit (PACU) upon following simple commands.

There were four analgesic drug protocols and according to that four groups: At the beginning of peritoneal closure all subjects received $0.15 \mathrm{mcg} / \mathrm{kg}$ morphine (M group). Some subjects additionally received $100 \mathrm{mg}$ ketoprofen (MK group) or $30 \mathrm{mg}$ ketorolac (MZ group) or $1000 \mathrm{mg}$ paracetamol (MP group) respectively, in i.v. infusion over 30 minutes at the beginning of surgery plus $0.075 \mathrm{mcg} / \mathrm{kg}$ at the same time point as in $\mathrm{M}$ group.

In the PACU, pain was assessed on regular 10-minute intervals and patients received additional $2 \mathrm{mg}$ morphine boluses in order to maintain the Numeric Pain Rating Scale (NPRS) score $£ 3$. Discharge readiness from the PACU was assessed by using the modified Aldrete's score every 15 minutes until patients met discharge criteria (score $\leq 9$ ) (21). Administrations of study analgesics were continued on the ward according to the following scheme during the first 48 hours after surgery: subjects in the M subgroup received i.v. boluses of morphine 5 mg every 4 hours , in MK subgroup received ketoprofen $100 \mathrm{mg} / 8 \mathrm{~h}$ i.v. infusion, in $\mathrm{MZ}$ - ketorolac $30 \mathrm{mg} / 8$ hours i.v. infusion and in MP received paracetamol $1000 \mathrm{mg}$ every 6 hours i.v. infusion. Additional analgesia for patients in all subgroups was performed on demand with the administration of $2 \mathrm{mg}$ of i.v. boluses of morphine until achieving NPRS score of $£ 3$.

\section{Patients' variables and quality of postoperative recovery assessments}

Perioperative data collected included subject's age, ASA physical class, smoking habits, duration of surgery. One of the investigators not involved with patient care performed perioperative data collection. Pain intensity was measured using a 10-point Numeric Pain Rating Scale (NPRS) on 10-minute intervals in PACU and on every four hours on the ward. The postoperative recovery was the primary study outcome and it was assessed using the researcher-assisted, 40-item questionnaire which was specifically designed and validated to measure a patient's health status after surgery and anesthesia (22). This questionnaire measures 5 dimensions of recovery: emotional state (9 items), physical comfort (12 items), psychological support (7 items), physical independence (5 items) and pain (7 items). The sum of the individual components generates an aggregate score, which we considered to be the primary study variable, ranging from 40 (the worst) to 200 (the best) points. We validated the Serbian language version internally, based on previous recommendation for clinical researchers (1).

\section{Oxidative stress markers measurements}

Venous blood samples were collected before the surgery in the preoperative room before saline infusion (T0), 3 hours (T1), 24 hours (T2) , 48 hours (T3) and 72 hours (T4) after the surgery. Samples $(5-10 \mathrm{~mL})$ were taken in tubes. Blood samples were taken from antecubital veins into test tubes containing sodium citrate anticoagulant. Blood samples were processed and stored immediately. Blood was centrifuged to separate plasma and red blood cells (RBCs). Biochemical parameters were measured spectrophotometrically.

\section{Index of lipid peroxidation (Thiobarbituric Acid Re-} active Substances, TBARS)

The degree of lipid peroxidation in plasma was estimated by measuring thiobarbituric acid reactive substances (TBARs) using 1\% thiobarbituric acid (TBA) in $0.05 \mathrm{M} \mathrm{NaOH}$, incubated with plasma at $100^{\circ} \mathrm{C}$ for $15 \mathrm{~min}$ and read at $530 \mathrm{~nm}$. Distilled water was used as a blank probe. TBA extract was obtained by combining $0.8 \mathrm{~mL}$ of plasma and $0.4 \mathrm{~mL}$ of trichloroacetic acid (TCA), and then the samples were put on ice for 10 minutes and centrifuged for $15 \mathrm{~min}$ at $6000 \mathrm{rpm}$ (23).

\section{Nitrite $\left(\mathrm{NO}_{2}^{-}\right)$}

Nitric oxide (NO) decomposes rapidly to form stable metabolite nitrite/nitrate products. Nitrite $\left(\mathrm{NO}_{2}^{-}\right)$was determined as an index of nitric oxide production with Griess's reagent: $0.1 \mathrm{~mL} 3 \mathrm{~N}$ perchloric acid (PCA), $0.4 \mathrm{~mL} 20 \mathrm{mM}$ ethylenediaminetetraacetic acid (EDTA), and $0.2 \mathrm{~mL}$ plasma were put on ice for $15 \mathrm{~min}$, then centrifuged for $15 \mathrm{~min}$ at $6000 \mathrm{rpm}$. After pouring of the supernatant, $220 \mu \mathrm{L}$ K2CO3 was added. Nitrites were measured at $550 \mathrm{~nm}$ of wavelength. Distilled water was used as a blank probe (24).

\section{Superoxide anion radical $\left(\mathrm{O}_{2}^{-}\right)$}

The level of superoxide anion radical $\left(\mathrm{O}_{2}^{-}\right)$was measured using nitro blue tetrazolium (NBT) reaction in TRISbuffer combined with plasma samples and read at $530 \mathrm{~nm}$. Distilled water was used as a blank probe (25). 


\section{Hydrogen peroxide $\left(\mathrm{H}_{2} \mathrm{O}_{2}\right)$}

The protocol for measuring hydrogen peroxide $\left(\mathrm{H}_{2} \mathrm{O}_{2}\right)$ was based on oxidation of phenol red in the presence of horseradish peroxidase. Two hundred $\mu \mathrm{L}$ sample with 800 $\mu \mathrm{L}$ phenol red solution (PRS) and $10 \mu \mathrm{L}$ horseradish peroxidase (PD) were combined (1:20). The level of $\mathrm{H} 2 \mathrm{O} 2$ was measured at $610 \mathrm{~nm}(26)$.

\section{Determination of activities of antioxidant enzymes}

Hemoglobin determination, necessary for the calculation of activity of endogenous antioxidants, was performed according to the Drabkin method. Superoxide dismutase (SOD) activity was determined by the epinephrine method of Misra and Fridovich (27). A hundred $\mu \mathrm{L}$ lysate and 1 $\mathrm{mL}$ carbonate buffer were mixed, and then $100 \mu \mathrm{L}$ of epinephrine were added. Detection was performed at $470 \mathrm{~nm}$. Plasma levels of reduced glutathione (GSH) are determined spectrophotometrically by Buetler's method, based on the oxidation of glutathione (GSH) by 5,5'-dithiobis(2-nitrobenzoic acid) (DTNB) (28) . Catalase (CAT) activity was determined according to Beutler. Lysates were diluted with distilled water $(1: 7 \mathrm{v} / \mathrm{v})$ and treated with chloroform-ethanol $(0.6: 1 \mathrm{v} / \mathrm{v})$ to remove hemoglobin. Then $50 \mu \mathrm{L}$ catalase buffer, $100 \mu \mathrm{L}$ sample, and $1 \mathrm{~mL} 10 \mathrm{mM} \mathrm{H} 2 \mathrm{O} 2$ were mixed. Detection was performed at $360 \mathrm{~nm}$. Distilled water was used as a blank probe (28).

\section{Statistical analysis}

Sample size calculation assumed differences between baseline and final QoR-40 total score of at least 10 points ( $5 \%)$, for pairwise comparisons (matched pairs), with $\mathrm{a}=0.05$ and $\mathrm{b}=0.2$, based on data from similar studies (1, 29). The preliminary calculated size was increased 1.5 times (assumption of non-parametric distribution and higher variability of study data than expected), establishing the final study population of at least 45 subjects . Statistical analysis included description methods, analysis of variance (one-way and repeated measures pairwise comparisons), Friedman test, Kruskal Wallis test, Wilcoxon Signed Rank test, and correlations (Pearson, Spearman's rho). For the purpose of secondary analysis the patients have been divided into four subgroups according to the prescribed analgesic protocol: morphine only $(\mathrm{M})$, morphine plus ketoprofen (MK), morphine plus ketorolac (MK) and morphine and paracetamol (MK). All statistical tests were performed two-sided and the differences were considered statistically significant at the level of $\mathrm{p} £ 0.05$.

\section{RESULTS}

\section{Patients' characteristics}

Study population included 51 females, average age $51.6 \pm 78$ years (the mean \pm standard deviation-SD), the youngest was 39 and the oldest was 69 years old. Among

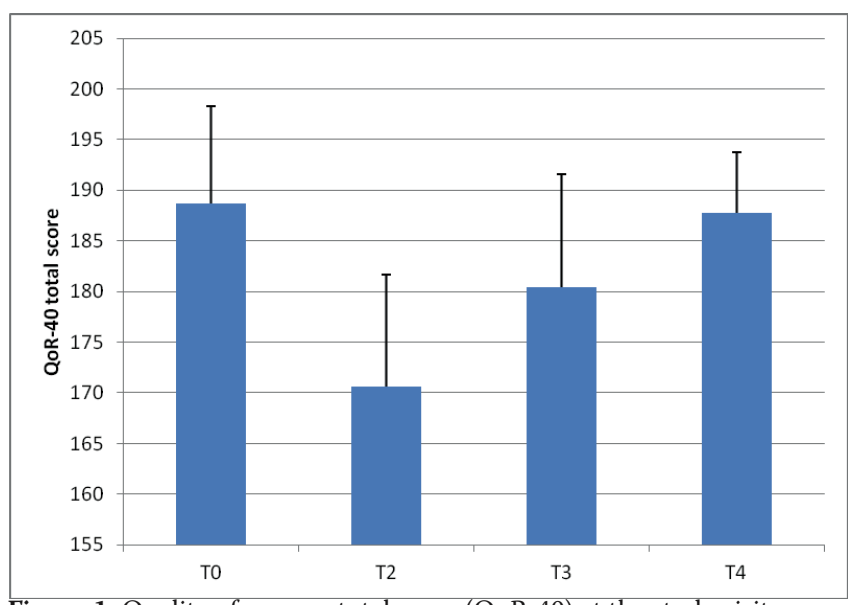

Figure 1. Quality of recover total score (QoR-40) at the study visits.

them $76.5 \%$ were ASA I $(n=39), 23.5 \%$ ASA II $(n=12)$ and $43.1 \%$ were smokers $(n=22)$. Average duration of surgery was $74.8 \pm 26.4$ minutes (minimum 35 minutes and maximum 120 minutes). There were four study subgroups according to the principal analgesic drug protocol: 19 women (37.3\%) received morphine $(\mathrm{M}), 14$ women $(27.5 \%)$ received morphine plus ketoprofen (MK), 6 women (13.7\%) received morphine plus ketorolac (MZ) and 7 women (13.7\%) received morphine plus paracetamol (MP). Five patients received analgesic combinations which did not fit into abovementioned, prespecified classification and their data had been not included for analgesic subgroup analysis. There were no statistically significant differences in patients characteristics between subjects from different groups ( $p>0.05)$. In addition, exclusion criteria in our study eliminated differences in distribution of variety of other factors that could affect our outcomes.

\section{Quality of recovery}

Total QoR-40 score decreased during early postoperative period and returned at preoperative values within three days (figure 1). In general, the scores during the study changed significantly $(\mathrm{p}<0.001$; ANOVA-repeated measures) with significantly lower values on the POD1 and POD2 ( $<<0.05$; ANOVA-repeated measures, pairwise comparisons).

In general, observed changes of QoR-40 total scores were similar between subgroup of patients receiving different analgesics drugs. Only on the first postoperative day the differences were statistically significant between groups ( $\mathrm{p}=0.039$; one-way ANOVA). The patients in MK group had a smaller drop of the scores $(\mathrm{n}=8$, the mean decrease $=10.6$ points, $\mathrm{SD}=6.5, \min =-1, \max =18)$ than patients in MZ group (6, 23.2, 17.2, 7, 54) or M group (11, 25.6, 12.0, 4, 46).

\section{Oxidative stress markers}

The values of oxidative stress partameters in the whole study population were presented in the table 1 . The de- 
Table 1. The values of oxidative stress markers before (T0), 3 (T1), 24 (T2), 48 (T3) and 72 (T4) hours after the surgery in whole study population (n=51)

\begin{tabular}{lcccc} 
Parameter & T0 & T1 & T2 & T3 \\
TBARS $(\mu \mathrm{mol} / \mathrm{ml})$ & $3.23 \pm 2.26$ & $3.63 \pm 2.62$ & $3.74 \pm 2.43$ & $3.64 \pm 2.30$ \\
$\mathrm{NO}_{2}(\mathrm{nmol} / \mathrm{ml})$ & $10.37 \pm 7.62$ & $9.58 \pm 7.88$ & $10.15 \pm 7.93$ & $9.38 \pm 7.56$ \\
$\mathrm{H}_{2} \mathrm{O}_{2}(\mathrm{nmol} / \mathrm{ml})^{*}$ & $2.47 \pm 2.32$ & $1.94 \pm 1.41$ & $1.85 \pm 1.43$ & $2.36 \pm 1.83$ \\
$\mathrm{O}_{2}(\mathrm{nmol} / \mathrm{ml})$ & $6.91 \pm 4.25$ & $6.54 \pm 3.83$ & $8.53 \pm 5.07$ & $7.48 \pm 5.27$ \\
$\mathrm{SOD}\left(\mathrm{U} / \mathrm{gHgbx} 10^{4}\right)$ & $584.09 \pm 1065.07$ & $695.88 \pm 1298.00$ & $507.21 \pm 675.36$ & $570.68 \pm 692.91$ \\
$\mathrm{GSH}(\mathrm{nmol} / \mathrm{ml})$ & $5826.29 \pm 4093.37$ & $6586.89 \pm 8246.42$ & $6869.54 \pm 6654.74$ & $8059.70 \pm 12197.24$ \\
$\mathrm{CAT}\left(\mathrm{U} / \mathrm{gHgbx} 10^{4}\right)$ & $133.45 \pm 144.76$ & $103.06 \pm 87.99$ & $97.27 \pm 117.51$ & $7556.66 \pm 8731.99$ \\
\hline
\end{tabular}

Table 2. The values of oxidative stress markers before (T0), 3 (T1), 24 (T2), 48 (T3) and 72 (T4) hours after the surgery in whole study population (repeated measures analysis)

\begin{tabular}{|c|c|c|c|c|c|c|}
\hline Parameter & $\mathbf{N}$ & T0 & T1 & T2 & T3 & T4 \\
\hline TBARS $(\mu \mathrm{mol} / \mathrm{ml})$ & 29 & $0.13 \pm 11.21$ & $0.04 \pm 10.97$ & $0.71 \pm 9.70$ & $9.70 \pm 9.70$ & $0.26 \pm 10.24$ \\
\hline $\mathrm{NO}_{2}(\mathrm{nmol} / \mathrm{ml})$ & 29 & $1.42 \pm 23.47$ & $1.46 \pm 31.44$ & $1.38 \pm 26.60$ & $0.04 \pm 35.20$ & $1.75 \pm 23.01$ \\
\hline $\mathrm{H}_{2} \mathrm{O}_{2}(\mathrm{nmol} / \mathrm{ml})^{*}$ & 27 & $2.65 \pm 2.30$ & $2.11 \pm 1.31$ & $2.08 \pm 1.25$ & $2.59 \pm 1.54$ & $2.96 \pm 2.34$ \\
\hline $\mathrm{O}_{2}(\mathrm{nmol} / \mathrm{ml})$ & 29 & $6.24 \pm 3.04$ & $6.52 \pm 3.77$ & $7.91 \pm 4.67$ & $6.56 \pm 4.67$ & $6.29 \pm 4.72$ \\
\hline SOD (U/gHgbx10 $)$ & 31 & $642.80 \pm 1237.00$ & $889.62 \pm 1522.65$ & $359.47 \pm 354.45$ & $626.52 \pm 791.88$ & $605.77 \pm 672.69$ \\
\hline GSH (nmol/ml) & 31 & $5454.66 \pm 4464.90$ & $6531.01 \pm 9169.65$ & $6974.39 \pm 7429.45$ & $9515.30 \pm 14367.34$ & $7556.66 \pm 8731.99$ \\
\hline CAT (U/gHgbx104) & 30 & $134.95 \pm 160.69$ & $84.27 \pm 76.76$ & $109.14 \pm 134.52$ & $117.00 \pm 141.61$ & $102.15 \pm 143.04$ \\
\hline
\end{tabular}

*p $<0.05$ between study visits

scriptive statistics included all study subjects $(n=51)$, i.e. those with missing data at some visits.

TBARS levels values across five measurements were not statistically significant ( $\mathrm{p}=0,633$; Fiedman test). Although the parameter, in general, increased during the study the individual variability was very high and the differences did not reach the threshold of statistical significance (table 2).

Nitrite $\left(\mathrm{NO}_{2}^{-}\right)$values across five study visits were not statistically significant ( $p=0,633$; Fiedman test). The individual variability was even higher than in other parameters (table 2).

Hydrogen peroxide $\left(\mathrm{H}_{2} \mathrm{O}_{2}\right)$ values significantly decreased from baseline to $\mathrm{T} 3$ and then, increased at the end of the study period (table 2). Overall, the differences across the study visits were statistically significant $(\mathrm{p}=0,011$; Fiedman test). Statistically significant differences of hydrogen peroxide $\left(\mathrm{H}_{2} \mathrm{O}_{2}\right)$ values in patients' serum samples have been observed between the following study visits T0 and T2 ( $\mathrm{p}=0.044$; Wilcoxon Signed Ranks test), T1 and T3 ( $\mathrm{p}=0.040$; Wilcoxon Signed Ranks test), T1 and T4 (p=0.036; Wilcoxon Signed Ranks test), T2 and T3 ( $\mathrm{p}=0.003$; Wilcoxon Signed Ranks test and, T2 and T4 ( $\mathrm{p}=0.007$; Wilcoxon Signed Ranks test).

Superoxide anion radical $\left(\mathrm{O}_{2}^{-}\right)$values across five study visits were not statistically significant $(p=0,293$; Fiedman test). The individual variability was slight and it seems further suggesting of the stability of the production of this molecule during the study period (table 5).

There were not statistically significant differences of superoxide dismutase (SOD) values during the study $(p=0,769$; Fiedman test). The individual variability was rather high and notable difference particularly between $\mathrm{T} 1$ and $\mathrm{T} 2$ visit did not significantly affected overall trend of the parameter (table 2).

There were not statistically significant differences of reduced glutathione (GSH) values during the study $(p=0,114$; Fiedman test). The individual variability was high, too and notable difference particularly between T0 and T3 (almost doubling the mean values) visits did reached statistical significance (table 2).

Catalase (CAT) values across five measurements were not statistically significant ( $p=0,317$; Fiedman test). Although the parameter, in general, decreased during the study the differences did not reach the threshold of statistical significance (table 2).

\section{Correlation analysis of oxidative stress markers and QoR-40}

There were no significant correlation between the values of parameters of oxidative stress response, except in the case of TBARS and $\mathrm{H}_{2} \mathrm{O}_{2}$. The values of changes from T0 to T3 of TBARS and the values of changes in the same period ( $\mathrm{T} 0$ to $\mathrm{T} 3$ ) of $\mathrm{H}_{2} \mathrm{O}_{2}$ significantly and negatively correlated with each other $(\mathrm{r}=-0.303, \mathrm{p}=0.046$; Spearman's rho). Finally, there were no significant correlation between total QoR-40 and any parameter of oxidative stress response, neither for their absolute values nor their changes between study visits.

\section{Oxidative stress markers, analgesics and other factors}

The differences of the means of TBARS changes from the baseline to T3 were statistically significant between 
the analgesic study subgroups ( $\mathrm{p}=0,031$; Kruskal Wallis test). These alterations originated from statistically significant differences between the values of ketorolac and paracetamol subgroups ( $\mathrm{p}=0.004$; Mann-Whitney-Wilcoxon test) as well as between morphine and paracetamol subgroups ( $\mathrm{p}=0.015$; Mann-Whitney-Wilcoxon test). Overall, the largest changes was noted in paracetamol study subgroups in which there was substantial increase of TBARS activity from $\mathrm{T} 0$ to $\mathrm{T} 3$ visits and then, the sudden drop to the end of the study period (figure 2).

There were no statistically significant differences between valuse of other oxidative stress response markers $\left(\mathrm{NO}_{2}-\mathrm{H}_{2} \mathrm{O}_{2}, \mathrm{O}_{2}^{-}, \mathrm{SOD}, \mathrm{GSH}, \mathrm{CAT}\right)$ during the study period regarding different analgesics subgroups ( $\mathrm{p}>0.05$; Kruskal Wallis test).

Patients age, duration of surgery and cigarette smoking status showed some significant influcences on and association with the oxidative stress response markers. Patients age negativelly correlated with TBARS changes from T0 to $\mathrm{T} 2(\mathrm{r}=-0.359, \mathrm{p}=0.032$; Spearman's $\mathrm{rho})$ and positively with CAT changes ( $r=0.363, p=0.025$; Spearman's rho). Duration of surgery correlated negatively with $\mathrm{O}_{2}$ - changes from T0 to T1( $\mathrm{r}=-0.388, \mathrm{p}=0.016$; Spearman's rho) and positively with CAT changes from T0 to T2 positively $(r=0.327$, $\mathrm{p}=0.045$; Spearman's rho). There were statistically signif-

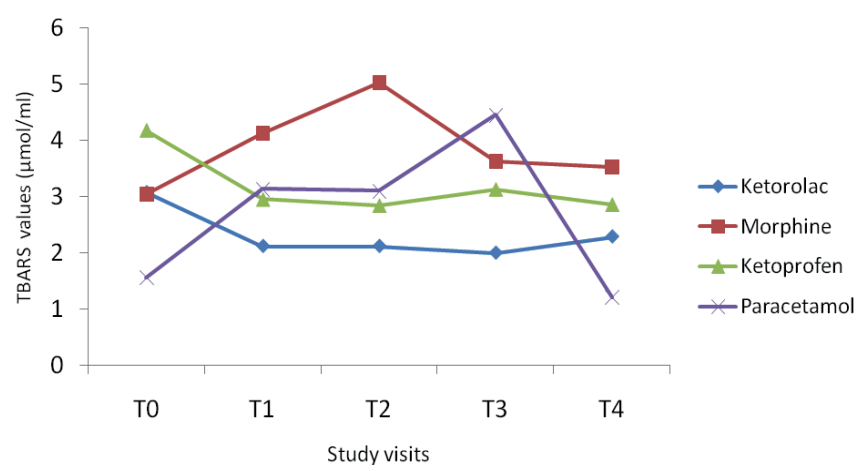

Figure 2. Median values of TBRAS $(\mu \mathrm{mol} / \mathrm{ml})$ between the analgesic study subgroups during the study period; ketorolac $(n=6)$, morphine $(n=19)$, ketoprofen $(n=14)$, paracetamol $(n=7)$, all non-opioid subgroup subjects received baseline analgesia with morphine (see methods).

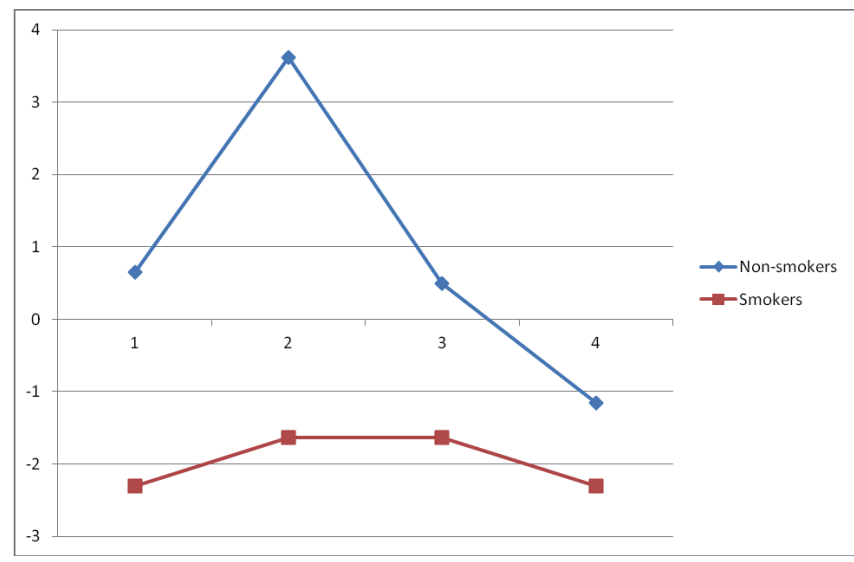

Figure 3. The median of changes from baseline (TO) of $\mathrm{O}_{2}^{-}$values in subgroup of cigarette smokers and non-smokers. icant differences of $\mathrm{O}_{2}^{-}$changes from T0 to T1 between the cigarette smokers and non-skomers $(\mathrm{p}=0.005$; MannWhitney-Wilcoxon test) as well as from T0 to T2 ( $\mathrm{p}=0.008$; Mann-Whitney-Wilcoxon test) (figure 3).

In addition, there were statistically significant changes of SOD from T0 and T1 between cigarette smokers and non-smokers ( $\mathrm{p}=0.045$; Mann-Whitney-Wilcoxon test). In the smokers the median of change was $-268.62(-1554.74$ and -81.40 , percentile 25 and 75 , respectively) and in the non-smokers the median of change was $252.34(-32.56$, 529.10)

\section{DISCUSSION}

The results of our study revealed that there was significant decrease of hydrogen peroxide $\left(\mathrm{H}_{2} \mathrm{O}_{2}\right)$ in women after abdominal hysterectomy in all patients 24 hours after surgery. In addition, there was significant increase of index of lipid peroxidation (measured as thiobarbituric acid reactive substances - TBARS activity) during 48 hours postoperatively in the MP subgroup. Correlation analysis confirmed this type of negative relationships between these two parameters of oxidative stress response. Only a few studies published so far investigated parameters of oxidative stress response in women after hysterectomy (18-20, 30). In addition, data about $\mathrm{H}_{2} \mathrm{O}_{2}$ activity lack and, therefore, our results represent the novelty in the field.

The several enzyme cascades are involved in the synthesis and the degradation of $\mathrm{H}_{2} \mathrm{O}_{2}$ including SOD, CAT, GPx, GSH and myeloperoxidase (31). However, in our study activities of SOD and CAT were insignificantly changed which suggest that other, unmeasured, alternative pathways were involved in observed decrease of $\mathrm{H}_{2} \mathrm{O}_{2}$. It is known for example that $\mathrm{H}_{2} \mathrm{O}_{2}$ could be removed with reactions mediated with free metal ions (e.g. $\left.\mathrm{Fe}^{2+}, \mathrm{Cu}^{2+}\right)$ during which very toxic, hydroxyl radical $\left(\mathrm{OH}_{\bullet}\right)$ is formed (Fenton's reaction). Therefore, it seems that, in fact, the decrease of $\mathrm{H}_{2} \mathrm{O}_{2}$ was, in essence, rather a marker of the very pro-oxidation state then an indicator of higher activity of oxidative stress defense mechanism during early postoperative period after abdominal hysterectomy (32). Indeed, there were a plenty of proteins such as ferritin, transferrin, hemoglobin, myoglobin and other metalloproteins which could release free metal ions from the tissues during the surgical trauma, then sequestering $\mathrm{H}_{2} \mathrm{O}_{2}$, liberating $(\mathrm{OH} \bullet)$ and finally making pro-oxidant state in the immediate postoperative period (32-34). Our finding about significant, negative correlation between $\mathrm{H}_{2} \mathrm{O}_{2}$ (decrease) and TBARS (increase), which is a marker of lipid peroxidation, further support that conclusion.

The effect of analgesic drugs could be additional mechanism of the decrease of $\mathrm{H}_{2} \mathrm{O}_{2}$ in our study subjects. All women received baseline morphine analgesia and the others paracetamol or a non-steroidal anti-inflammatory drug (NSAID), as well. Previous researches showed that morphine could dose-dependently decrease free radical 
synthesis in some surgical patients and increase $\mathrm{H}_{2} \mathrm{O}_{2}$ degradation exploiting remarkable antioxidative activity (16, $35)$. It is known that NSAIDs and paracetamol could also increase synthesis of $\mathrm{OH}$ • during Fenton's reaction which is also a mechanism of $\mathrm{H}_{2} \mathrm{O}_{2}$ sequestration, as described above (36).

The time-limited and paracetamol-dependent increase of TBARS (marker of lipid peroxidation) detected in our study could be consequences of at least two circumstances: methodological specificity of the TBARS assay and effects of analgesic drugs. The assay used for determination of TBARS is based on measurement of malonyldialdehyde (MDA) concentration. The synthesis and degradation of this metabolite is variable depending on many factors such as the types and content of polyunsaturated free fatty acid in lipid membrane and the contribution of both non-enzymatic and non-lipid pathways (37).

Morphine, during experimental oxidative stress conditions, which included the presence of adenosine diphosphate (ADP) and ferrous ion, prevented the lipid peroxidation due to inhibition of oxygen consumption and $\mathrm{H}_{2} \mathrm{O}_{2}$ generation (38). However, in other methodological settings this effect was either absent or achieved with high doses of morphine $(39,40)$. The use of paracetamol, on the other side, is associated with the consumption of a powerful antioxidant molecule, GSH, due to conjugation of its metabolites during the phase 2 of the drug's biotransformation $(41,42)$. This fact support our results that the subgroup of women, which received paracetamol, was more susceptible for development of pro-oxidant state than the others.

In our study, the concentration of other parameters of oxidative stress (SOD, CAT, $\mathrm{NO}, \mathrm{O}_{2}^{-}$), as well as GSH did not differ in successive plasma samples, either in whole patients population or in individual ones subgroups. Although the results of other, previously published studies in the field are not fully consistent and some of them support our findings this part of our study could be interpreted bearing the mind several its limitation (43). Firstly, our study sample was not very large, being underpowered for detecting significant differences but of smaller magnitudes. Secondly, the influence of other confounders, not included in our analysis could not be excluded. Finally, it is difficult to extrapolate our results to the patients treated in other clinical setting, such as receiving other type of anesthetic and analgesics drugs. Obviously, future research with more focused designs is needed in order to provide additional valid evidences.

The effects of age, duration of surgery and cigarette smoking in our study are further evidences about the disturbances of pathways of oxidative stress response at the time of at abdominal hysterectomy and during postoperative period. We noted disturbances of concentrations/activities of TBARS, $\mathrm{O}_{2}^{-}$, CAT and SOD pointing to activation of some pro-oxidant mechanisms and compensatory synthesis of some enzymes of antioxidative defense. All these factors are known triggers of oxidative stress response cascades but small numbers of cases in our research as well as the parameter- and time-dependent changes precluded more detailed analysis of their influence on the main study outcomes $(44,45)$.

The quality of recovery in women included in our study did not correlate with any of measured oxidative stress response parameter. The use of quality of recovery with QR-40 instrument had been validated in many studies with surgical patients in general anesthesia including women after abdominal hysterectomy (1). However, according to our knowledge, there were no studies, that particularly explored association between postoperative quality of recovery (e.g. QR-40 scores) and pro-oxidant reactive species or biomarkers of oxidative stress defense. In one recent research both MDA and quality of recovery score were assessed during 24 hours after Gynecologic Laparoscopic Surgery but no direct relationships between the two variables were established and reported (46). In general, studies dealing with postoperative recovery more often investigated other important biological pathways like cytokine response than oxidative stress parameters (4).

In conclusion, our findings suggest that during the hysterectomy women experienced a detectable degree of damage of cell membranes by lipid peroxidation type and that the subgroup that received paracetamol is under the highest risk. Of all the analgesics used, paracetamol has the highest potential for exhaustion of antioxidant defense mechanisms particularly in the presence of other stressors, which liberate reactive, pro-oxidant species as if it is a surgical intervention. Our study is, as we are aware, the first one, which in a comparative design, by the same method, examined the differences between different analgesics on parameters of lipid peroxidation and other indicators of oxidation stress during abdominal hysterectomy.

\section{ACKNOWLEDGMENT}

The authors thanks to Faculty of Medical Sciences of University of Kragujevac, Kragujevac, Serbia, for supporting the research with the Junior Project, JP 09-12, "Analysis of factors associated with postoperative recovery in patients after elective abdominal hysterectomy".

\section{REFERENCES}

1. Catro-Alves LJ, De Azevedo VL, De Freitas Braga TF, Goncalves AC, De Oliveira GS Jr. The effect of neuraxial versus general anesthesia techniques on postoperative quality of recovery and analgesia after abdominal hysterectomy: a prospective, randomized, controlled trial. Anesth Analg 2011; 113: 1480-6.

2. Chen JQ, Wu Z, Wen LY, Miao JZ, Hu YM, Xue R. Preoperative and postoperative analgesic techniques in the treatment of patients undergoing transabdominal hysterectomy: a preliminary randomized trial. BMC Anesthesiol 2015; 15: 70. 
3. Allvin R, Berg K, Idvall E, Nilsson U. Postoperative recovery: a concept analysis. J Adv Nurs 2007; 57: 552-8.

4. Bekker A, Haile M, Kline R, Didehvar S, Babu R, Martiniuk F, Urban M. The effect of intraoperative infusion of dexmedetomidine on quality of recovery after major spinal surgery. J Neurosurg Anesthesiol 2013; 25: 16-24.

5. Freide K, Mathew JP, Podgoreanu MV. Genomic basis of perioperative medicine. In: Barash PG, Culen BF, Stoelting RK, Cahalan MK, Stock MC, Ortega R, eds. Clinical anesthesia. 7th ed. Philadelphia: Lippincott Williams and Wilkins, 2013: 130-55.

6. Desborough JP. The stress response to trauma and surgery. Br J Anaesth 2000; 85: 109-17.

7. Kennedy G, Spence VA, McLaren M, Hill A, Underwood C, Belch JJ. Oxidative stress levels are raised in chronic fatigue syndrome and are associated with clinical symptoms. Free Radic Biol Med 2005; 39: 584-9.

8. Verit FF, Erel O, Sav M, Celik N, Cadirci D. Oxidative stress is associated with clinical severity of nausea and vomiting of pregnancy. Am J Perinatol 2007; 24: 545-8.

9. Cordero MD, Cano-García FJ, Alcocer-Gómez E, De Miguel M, Sánchez-Alcázar JA. Oxidative stress correlates with headache symptoms in fibromyalgia: coenzyme $\mathrm{Q}_{10}$ effect on clinical improvement. PLoS One 2012; 7(4): e35677.

10. Michel TM, Pülschen D, Thome J. The role of oxidative stress in depressive disorders. Curr Pharm Des 2012; 18: 5890-9.

11. Kulacoglu H, Ozdogan M, Gurer A, Ersoy EP, Onder Devay A, Duygulu Devay S, Gulbahar O, Gogkus S. Prospective comparison of local, spinal, and general types of anaesthesia regarding oxidative stress following Lichtenstein hernia repair. Bratisl Lek Listy 2007; 108: 335-9.

12. Mas E, Barden AE, Corcoran TB, Phillips M, Roberts LJ2nd, Mori TA. (2011). Effects of spinal or general anesthesia on $\mathrm{F}_{2}$-isoprostanes and isofurans during ischemia/reperfusion of the leg in patients undergoing knee replacement surgery. Free Radic Biol Med 2011; 50: 1171-6.

13. Rosenfeldt F, Wilson M, Lee G, Kure C, Ou R, Braun L, de Haan J. (2013). Oxidative stress in surgery in an ageing population: pathophysiology and therapy. Exp Gerontol 2013; 48: 45-54

14. McDonald CI, Fraser JF, Coombes JS, Fung YL. Oxidative stress during extracorporeal circulation. Eur J Cardiothorac Surg 2014; 46: 937-43.

15. McAnulty SR, Owens JT, McAnulty LS, Nieman DC, Morrow JD, Dumke CL, Milne GL. Ibuprofen use during extreme exercise: effects on oxidative stress and PGE2. Med Sci Sports Exerc 2007; 39: 1075-9.

16. Fricova J, Vejrazka M, Stopka P, Krizova J, Belacek J, Rokyta R. The influence of preemptive analgesia on postoperative analgesia and its objective evaluation. Arch Med Sci 2010; 6: 764-71.

17. Koelsch M, Mallak R, Graham GG, Kajer T, Milligan MK, Nguyen LQ, Newsham DW, Keh JS, Kettle AJ, Scott
KF, Ziegler JB, Pattison DI, Fu S, Hawkins CL, Rees MD, Davies MJ. Acetaminophen (paracetamol) inhibits myeloperoxidase-catalyzed oxidant production and biological damage at therapeutically achievable concentrations. Biochem Pharmacol 2010; 79: 1156

18. Szymczyk G, Beltowski J, Marciniak A, Kotarski J. Assesment of serum lipid peroxide levels and antioxidant status in females who had undergone total abdominal hysterectomy without closing of peritoneum. Gin Pol 2003; 74: 1397-403.

19. Szymczyk G, Bełtowski J, Marciniak A, Kotarski J. Serum isoprostanes levels in patients after abdominal hysterectomy. Rocz Akad Med Bialymst 2005; 50: 322-4.

20. Kaur G, Mishra S, Kaur A, Sehgal A, Nageswari KS, Prasad R. Retention of ovaries and oxidative stress of surgery. Int J Gynaecol Obstet 2007; 97: 40-3.

21. Fowler MA, Spiess BD. Post anesthesia recovery. In: Barash PG, Culen BF, Stoelting RK, Cahalan MK, Stock MC, eds. Clinical anesthesia 6th ed. Philadelphia: Lippincott Williams and Wilkins, 2009: 1421-43.

22. Myles P, Weitkamp B, Jones K, Melick J, Hensen S. Validity and realibility of postoperative quality of recovery score: the QoR-40. British Journal of Anesthesia 2000; 84(1): 11-5.

23. Ohkawa H, Ohishi N, Yagi K. Assay for lipid peroxides in animal tissues by thiobarbituric acid reaction. Anal Biochem 1975; 95: 351-8.

24. Green LC, Wagner, DA, Glogowski J, Skipper PL, Wishnok JS, Tannenbaum SR. Analysis of nitrate, nitrite and [15N] nitrate in biological fluids. Anal Biochem 1982; 126: 131-8

25. Auclair C, Voisin E. Nitroblue tetrazolium reduction. In: Greenvvald RA, ed. Handbook of methods for oxygen radical research. Ine: Boka Raton, CRC Press, 1985: 123-32.

26. Pick E, Keisari Y. A simple colorimetric method for the measurement of hydrogen peroxide produced by cells in culture. J Immunol Methods 1980; 38: 161-70

27. Misra HP, Fridovich I. The role of superoxide-anion in the autooxidation of epinephrine and a simple assay for superoxide dismutase. J Biol Chem 1972; 247: 3170-5.

28. Beutler E. Red cell metabolism: a manual of biochemical methods. 3rd ed. New York: Grune and Stratton Inc., 1984.

29. Kane SM, Garcia-Tomas V, Alejandro-Rodriguez M, Astley B, Pollard RR. Randomized trial of transversus abdominis plane block at total laparoscopic hysterectomy: effect of regional analgesia on quality of recovery. Am J Obstet Gynecol 2012; 207: 419.e1-419.e5.

30. Sane AS, Chokshi SA, Mishra VV, Barad DP, Shah VC, Nagpal S. Serum lipoperoxide levels in surgical stress of abdominal hysterectomy. Panminerva Med 1993; 35: 131-3.

31. Lushchak V, Semchyshyn HM. Oxidative stress-molecular mechanisms and biological effects. Rijeka: InTech, 2012. (doi: 10.5772/2333).

32. Gutowski M, Kowalczyk S. A study of free radical chemistry: their role and pathophysiological significance. Acta Biochim Pol 2013; 60: 1-16. 
33. Halliwell B, Cross CE. Oxygen-derived species: their relation to human disease and environmental stress. Environ Health Perspect 1994; 102(Suppl 10): 5-12.

34. Valko M, Morris H, Cronin MT. Metals, toxicity and oxidative stress. Curr Med Chem 2005; 12: 1161-208.

35. Gülçin I, Beydemir S, Alici HA, Elmastaş $M$, Büyükokuroğlu ME. In vitro antioxidant properties of morphine. Pharmacol Res 2004; 49: 59-66.

36. Rozmer Z, Perjési P. Effect of some nonsteroid antiinflammatory drugs on Fentonreaction initiated degradation of 2-deoxy-D-ribose. Acta Pharm Hung 2005; 75: 69-75.

37. Repetto M, Semprine J, Boveris A. Lipid peroxidation: chemical mechanism, biological implications and analytical determination. Catala A, ed. Lipid peroxidation. Rijeka: InTech, 2012. (doi: 10.5772/45943).

38. Cunha-Oliveira T, Silva L, Silva AM, Moreno AJ, Oliveira CR, Santos MS. Acute effects of cocaine, morphine and their combination on bioenergetic function and susceptibility to oxidative stress of rat liver mitochondria. Life Sci 2013; 92: 1157-64.

39. Rokyta R, Holecek V, Pekárkova I, Krejcová J, Racek J, Trefil L, Yamamotová A. Free radicals after painful stimulation are influenced by antioxidants and analgesics. Neuro Endocrinol Lett 2003; 24: 304-9.

40. Horid'ko TM, Hula NM, Stohniǔ NA, Mehed' OF, Klimashevs'kyĭ VM, Shovkun SA, Kindruk NL, Berdyshev AH. Effect of N-stearoylethanolamine on the lipid peroxidation process and lipid composition of the rat liver in acute morphine intoxication. Ukr Biokhim $\mathrm{Zh}$ 2007; 79: 175-85.

41. Coen M. Metabolic phenotyping applied to pre-clinical and clinical studies of acetaminophen metabolism and hepatotoxicity. Drug Metab Rev 2015; 47: 29-44.

43. Mila-Kierzenkowska C, Woźniak A, Drewa T, Woźniak B, Szpinda M, Krzyżyńska-Malinowska E, Rajewski R. Effects of open versus laparoscopic nephrectomy techniques on oxidative stress markers in patients with renal cell carcinoma. Oxid Med Cell Longev 2013; 2013: 438321.

42. James LP, Mayeux PR, Hinson JA. Acetaminopheninduced hepatotoxicity. Drug Metab Dispos 2003; 31: 1499-506.

44. Koźlik J, Przybyłowska J, Mikrut K, Żukiewicz-Sobczak WA, Zwoliński J, Piątek J, Sobczak P. Selected oxidative stress markers in gynecological laparoscopy. Wideochir Inne Tech Maloinwazyjne 2015; 10: 92-100.

45. Mikhed Y, Daiber A, Steven S. Mitochondrial Oxidative Stress, Mitochondrial DNA Damage and Their Role in Age-Related Vascular Dysfunction. Int J Mol Sci 2015; 16: 15918-53.

46. Liao CC, Kau YC, Ting PC, Tsai SC, Wang CJ. The Effects of Volume-Controlled and Pressure-Controlled Ventilation on Lung Mechanics, Oxidative Stress, and Recovery in Gynecologic Laparoscopic Surgery. J Minim Invasive Gynecol 2016; 23: 410-7. 
$\$$ sciendo 